Research article

\title{
CHANGES IN BIOCHEMICAL PARAMETERS IN HORSES DURING 40 KM AND 80 KM ENDURANCE RACES
}

\author{
KLOBUČAR Karla ${ }^{1}$, VRBANAC Zoran²*, GOTIĆ Jelena ${ }^{3}$, BOJANIĆ Krunoslav ${ }^{4}$, \\ BUREŠ Tomislav ${ }^{1}$, BRKLJAČA BOTTEGARO Nika ${ }^{5}$
}

\begin{abstract}
${ }^{1}$ Faculty of Veterinary Medicine, University of Zagreb, Zagreb, Croatia; ${ }^{2}$ Department of Radiology, Ultrasound Diagnostic and Physical Therapy, Faculty of Veterinary Medicine, University of Zagreb, Zagreb, Croatia; ${ }^{3}$ Clinic for Internal Diseases, Faculty of Veterinary Medicine, University of Zagreb, Zagreb, Croatia; ${ }^{4}$ Center of Excellence for Marine Bioprospecting BioProCro, Laboratory for Aquaculture Biotechnology, Ruđer Bošković Institute, Zagreb, Croatia; ${ }^{5}$ Clinic for Surgery, Orthopaedics and Ophthalmology, Faculty of Veterinary Medicine, University of Zagreb, Zagreb, Croatia
\end{abstract}

(Received 22 January, Accepted 01 March 2019)

During intensive physical activity horses are exposed to thermolysis, electrolyte loss and rising amounts of catabolic products, which results in alterations of biochemical blood parameters due to the horse's adaptation to metabolic stress. The aim of the present study was to determine the effect of intensive physical activity on serum biochemical parameters in horses competing in 40 and $80 \mathrm{~km}$ endurance races. Blood samples were taken from 28 horses before and after the race over four competitions, with a total of 53 samples analyzed. Biochemical parameters studied included creatine kinase, lactate dehydrogenase, aspartate aminotransferase, urea, creatinine, gammaglutamyl transferase, glucose, triglycerides, cholesterol, sodium, potassium, calcium and magnesium. The extent of change in pre- and post-race values was compared between categories of age, gender, breed, distance and average speed of horses. Creatine kinase and blood glucose values prior to the race were higher than the reference values. Values of renal parameters and parameters of muscle damage increased after the races, and the degree of change was more pronounced at longer racing lengths, as well as at lower average speed. Electrolyte loss was more prominent during longer races. This study demonstrated that endurance races cause evident changes in serum electrolyte concentrations, renal parameters and markers of muscle damage in horses. These changes are observable in horses at both short and long duration endurance races.

Key words: exercise, horse, endurance, metabolism

\section{INTRODUCTION}

There is a wide range of metabolic and physical demands on horses in equine competitions. Exercise causes redistribution of fluids and electrolytes within the body

\footnotetext{
*Corresponding author: e-mail: zvrbanac@vef.hr
} 
compartments, resulting in a rapid decline in plasma volume following the onset of exercise, proportional to the intensity and duration of effort [1]. Prolonged submaximal aerobic exercise, such as endurance racing [2], causes cardiorespiratory, endocrine and neuromuscular systems to operate at an elevated level for an unnatural length of time $[3,4]$. During long races, horses are exposed to thermolysis, electrolyte loss and emergence of large amounts of catabolism products as a consequence of hemolysis, partial rhabdomyolysis, energy metabolism, and liver and kidney metabolism $[5,6]$.

Changes in hematological and biochemical blood parameters represent an adaptation of the individual horse to metabolic stress, or catabolic response of the body to physical activity, injury or disease. The effect of intense exercise on blood variables can be monitored during the race by obtaining blood samples, but may be challenging due to the perceived negative impact on the horse's performance. Changes in electrolyte and mineral concentrations with exercise are most likely to occur during high-intensity or prolonged submaximal exercise. During a long period of physical activity, the body temperature of the horse increases by $1-3{ }^{\circ} \mathrm{C}$ [7]. It has been reported by Robert et al. [8] that, in order to maintain homeostasis, the individual horse produces 10-15 liters of sweat per hour at an average speed of $16 \mathrm{~km} / \mathrm{h}$. That study also demonstrated that fluid losses were adequately balanced by water intake; however, renal reabsorption of sodium $(\mathrm{Na})$ and chloride $(\mathrm{Cl})$ were insufficient to compensate for electrolyte losses in sweat [8].

Increased concentrations of urea, total protein and sodium $(\mathrm{Na})$ after an endurance race are characteristic of horses trained for endurance riding [9]. After the race, the highest increase in serum biochemical values is observed in creatine kinase (CK) and aspartate aminotransferase (AST), which are serum indicators of muscle damage [10].

Of all equine competitions, endurance races have the greatest metabolic demands requiring substantial energy production for many hours [11]. The importance of selecting the appropriate horse and the processes involved in mental and physical conditioning of endurance horses are integral for success in endurance racing [12]. Horses of different breeds are used in endurance riding, although the most popular are Arabian horses, due to their lightweight construction and exceptional endurance $[5,6]$.

Previous studies of hematological and biochemical blood parameters in endurance horses $[2,4,13]$ have been performed on horses competing at distances from 80 to $160 \mathrm{~km}$. These distances are considered to be high to very high levels of exercise for a trained horse. Larsson et al. [10] investigated only mature endurance horses ( $\geq 7$ years of age) competing at distances from 65 to $120 \mathrm{~km}$, and showed that more experienced horses have a less pronounced increase in blood parameters indicating muscular damage in response to the race. Adamu et al. [14] investigated metabolic changes in horses competing at distances of 40, 80 and $120 \mathrm{~km}$ in relation to a metabolic index, which included creatine kinase as a predictor of the individual horse elimination at each distance. 
The aim of the present study was to determine the effect of endurance races on serum biochemical parameters in horses competing in 40 and $80 \mathrm{~km}$ races, as a vast majority of horses in this sport compete at these distances during lower level national endurance races. It was of interest to compare the obtained results within different distances. Furthermore, the aim was to determine if the age, gender and breed of the horse influenced the selected biochemical variables between pre- and post-race values. It was hypothesized that even short distance endurance races cause changes in metabolism that should be considered when assessing the condition of endurance horses in competition.

\section{MATERIAL AND METHODS}

\section{Competition and conditions}

Data were obtained about horses that took part in four national competitions held at different locations in Croatia from April to July 2017. There were two races held at each competition: of 40 and $80 \mathrm{~km}$ in distance. Participation in the study was voluntary, and horse owners were offered to participate in the study prior to the first veterinary inspection of their horses at the competition sites.

\section{Horses}

The inclusion criterion for horses was a successful completion of the race. All horses had been transported from different locations and were given a rest of at least two hours before the first veterinary examination. Horses were subjected to different diets and protocols of electrolyte supplementation, both during training and competition. The competitions included veterinary inspections before, during and after the race.

Horses were divided into groups by age; under the age of eight, and eight or older. Horses were also divided by gender into a group of males (stallions and geldings), and females. With regard to the breed, horses were divided into two groups: horses of Arabian breeds (horses of Arabian breeds and Arabian crossbreeds), and horses of other warm blood breeds. The average speed of horses in the study population was also evaluated with a cut-off of $14 \mathrm{~km} / \mathrm{h}$, which is the minimal average speed required for the Federation Equestre International 4* championship qualification [15].

\section{Sample collection and analysis}

Two $5 \mathrm{ml}$ blood samples were collected from each horse, the first sample approximately one hour prior to the race start and the second one 30 minutes after the end of the race. The blood samples were drawn by jugular venipuncture into vacuum tubes for serum with gel using a vacutainer (Vacutainer ${ }^{\circledR}$, Becton Dickenson, USA). The samples were left to coagulate for 30 minutes and subsequently centrifuged at $3500 \mathrm{rpm}$ for 15 
minutes. The samples were shipped in cooling bags at $4{ }^{\circ} \mathrm{C}$ to the laboratory where they were stored at $-80^{\circ} \mathrm{C}$ until further analyses.

The concentrations of urea, creatinine, glucose, triglycerides, cholesterol, calcium (Ca) and magnesium $(\mathrm{Mg})$ and activities of aspartate aminotransferase (AST), gammaglutamyl transferase (GGT), creatine kinase (CK) and lactate dehydrogenase (LDH) in blood serum were analyzed with Beckman Coulter ${ }^{\circledR}$ commercial kits using the Olympus AU640 (Olympus, Japan) biochemical analyzer. Concentrations of sodium $(\mathrm{Na})$ and potassium $(\mathrm{K})$ were determined using the SmartLyte electrolyte analyzer (Diamond Diagnostics, Germany).

Reference ranges were taken from the equine reference intervals used by the Laboratory of Veterinary Internal Medicine, Faculty of Veterinary Medicine Zagreb, where the samples were analyzed.

\section{Ethics approval and consent to participate}

The owners of horses included in the study gave a written consent statement for the participation in the study. The study was approved by the Ethical Board of the Faculty of Veterinary Medicine (File No. 640-01/16-17/75; Record No. 251-61-01/139-16-2).

\section{Statistical methods}

All exploratory data analyses and statistical tests were performed using $\mathrm{R}$ v3.2.21 [16]. The dependent variables of interest were the changes in values after the race compared to those before the race for each biochemical parameter. The explanatory variables of interest that were collected from horses (age, gender, breed and average speed), and race events characteristics (race distance) were evaluated within each subpopulation category and for comparisons between the respective subpopulation categories of horses. The average change was analyzed via hierarchical linear mixedeffects regression models using the lme4 software package [17]. Similarly, correlations of biochemical parameters were also adjusted for non-independence, i.e., repeated measurements on individual horses. The alpha level of significance for correlation tests, model fits and regression coefficients was taken at less than 0.05. Data were expressed as an average ( \pm standard error of mean (SEM)).

\section{RESULTS}

Owners of forty-five horses competing in four endurance races agreed to join the study. Given that certain individual horses participated in more than one race, there were 127 race starts in total. Twenty-eight individual horses with 53 race starts met the overall inclusion criteria. Out of the 28 horses included in the research, five participated in three competitions, fifteen in two competitions and eight horses in only 
one competition. There were 18 female and 10 male horses, with an average age of 7.3 ( \pm 0.3 SEM) years. There were 14 Arabian horses and 14 horses of other breeds.

With respect to race distance, there were 30 race starts at the $40 \mathrm{~km}$ distance and 23 race starts at the $80 \mathrm{~km}$ distance. The average speed of horses during the races was 13.5 ( $\pm 0.2 \mathrm{SEM}) \mathrm{km} / \mathrm{h}$. The average speed at $40 \mathrm{~km}$ races was 13.7 ( $\pm 0.3 \mathrm{SEM}$ ) and 13.2 ( $\pm 0.3 \mathrm{SEM}) \mathrm{km} / \mathrm{h}$ at $80 \mathrm{~km}$ races, with no significant difference in average speed due to distance $(\mathrm{p}=0.3)$.

The overall values of biochemical parameters of horses before and after competing in endurance races are presented in Table 1.

Table 1. Values of biochemical parameters in horses before and after races.

\begin{tabular}{|c|c|c|c|c|}
\hline Parameter & Reference values & Pre-race value & Post-race value & $\begin{array}{c}\% \text { change } \\
\text { Statistical } \\
\text { significance }\end{array}$ \\
\hline $\mathrm{CK}(\mathrm{U} / \mathrm{L})$ & $0-130$ & $374.89 \pm 40.89$ & $1083.9 \pm 126.6$ & $189 \% \uparrow \mathrm{p}<0.001$ \\
\hline $\mathrm{LDH}(\mathrm{U} / \mathrm{L})$ & $162-412$ & $403.16 \pm 17.33$ & $585.6 \pm 29.4$ & $45 \% \uparrow \mathrm{p}<0.001$ \\
\hline AST (U/L) & $0-490$ & $418.3 \pm 16.12$ & $493.6 \pm 19.2$ & $18 \% \uparrow \mathrm{p}<0.001$ \\
\hline Urea (mmol/L) & $3.3-6.6$ & $6.16 \pm 0.19$ & $8.68 \pm 0.26$ & $41 \% \uparrow \mathrm{p}<0.001$ \\
\hline Creatinine $(\mathrm{U} / \mathrm{L})$ & $0-115$ & $100.32 \pm 2.72$ & $134.01 \pm 3.5$ & $34 \% \uparrow \mathrm{p}<0.001$ \\
\hline GGT (U/L) & $0-28$ & $16.33 \pm 0.98$ & $16.93 \pm 0.98$ & NS* \\
\hline Glucose (U/L) & $3.1-5.0$ & $6.16 \pm 0.19$ & $6.36 \pm 0.31$ & NS \\
\hline Triglyceride (mmol/L) & $0.1-0.5$ & $0.22 \pm 0.02$ & $0.21 \pm 0.02$ & NS \\
\hline Cholesterol (mmol/L) & $1.8-4.6$ & $2.44 \pm 0.06$ & $2.59 \pm 0.06$ & $6 \% \uparrow \mathrm{p}<0.001$ \\
\hline $\mathrm{Na}(\mathrm{mmol} / \mathrm{L})$ & $132-146$ & $146.97 \pm 1.1$ & $144.61 \pm 0.99$ & $2 \% \downarrow p=0.004$ \\
\hline $\mathrm{K}(\mathrm{mmol} / \mathrm{L})$ & $2.4-4.7$ & $3.52 \pm 0.07$ & $2.64 \pm 0.06$ & $25 \% \downarrow p<0.001$ \\
\hline $\mathrm{Ca}(\mathrm{mmol} / \mathrm{L})$ & $2.5-3.4$ & $3.15 \pm 0.03$ & $3.18 \pm 0.03$ & NS \\
\hline $\mathrm{Mg}(\mathrm{mmol} / \mathrm{L})$ & $0.7-0.9$ & $0.87 \pm 0.01$ & $0.88 \pm 0.02$ & NS \\
\hline
\end{tabular}

$*$ Not significant $(\mathrm{P}>0.05) . \%=[($ mean post-race value - mean pre-race value $) /($ mean prevalue $) * 100]$.

Reference values given by the laboratory which performed the analyses.

The lowest measured concentration of $\mathrm{CK}$ before the race was $187.00 \mathrm{U} / \mathrm{L}$, while the highest was $1865.00 \mathrm{U} / \mathrm{L}$, with all measured values being higher than the normal reference range. Prior to the race, elevations over maximum reference values of glucose were observed in $94 \%$ of horses (48/53) and of urea in $28 \%$ of horses $(15 / 53)$.

Furthermore, before the race females had significantly higher concentrations of LDH $(p<0.01)$ and AST $(p=0.02)$ compared to males. Younger horses had a significantly higher concentration of LDH $(p<0.01)$ before the race than the older horses.

The values of biochemical parameters before and after competing in endurance races classified by age, gender and breed are presented in Table 2. Older horses had 
significantly higher changes in creatinine concentrations $(p=0.0081)$ compared to younger horses. Females had a significantly higher increase in urea concentrations ( $p$ $=0.044$ ) compared to males. With respect to breed, the concentration of $\mathrm{Mg}$ in other breeds recorded a significant change $(p<0.01)$ after the race compared to values before the race. The concentrations of GGT, glucose, triglyceride and $\mathrm{Ca}$ did not show significant changes before and after the races in any of these categories.

Table 2. Values of biochemical parameters in horses before and after races by age, gender and breed.

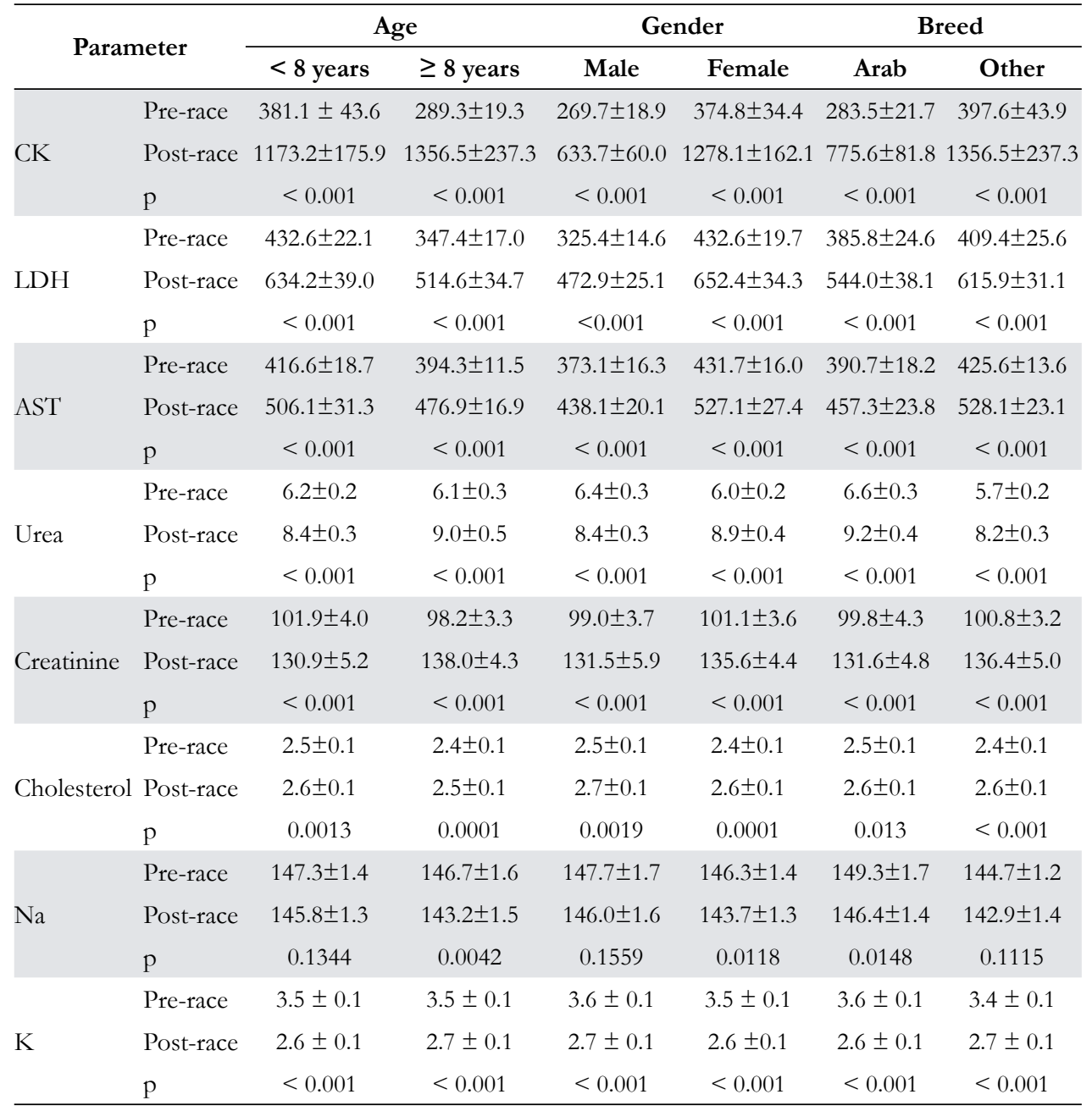

CK, creatine kinase; LDH, lactate dehydrogenase; AST, aspartate aminotransferase; Na, sodium; K, potassium

The values of biochemical parameters of horses before and after competing in endurance races in relation to categories of distance and average speed are presented in Table 3. 
Table 3. Values of biochemical parameters in horses before and after races by distance and average speed.

\begin{tabular}{|c|c|c|c|c|c|}
\hline \multirow{2}{*}{\multicolumn{2}{|c|}{ Parameter }} & \multicolumn{2}{|c|}{ Distance } & \multicolumn{2}{|c|}{ Average speed } \\
\hline & & $40 \mathrm{~km}$ & $80 \mathrm{~km}$ & $<14 \mathrm{~km} / \mathrm{h}$ & $\geq 14 \mathrm{~km} / \mathrm{h}$ \\
\hline \multirow{3}{*}{ CK } & Pre-race & $324.1 \pm 25.4$ & $349.6 \pm 38.6$ & $340.1 \pm 30.5$ & $313.7 \pm 24.6$ \\
\hline & Post-race & $689.8 \pm 49.5$ & $1623.9 \pm 277.5$ & $1222.3 \pm 200.7$ & $1004.4 \pm 153.8$ \\
\hline & $\mathrm{p}$ & $<0.001$ & $<0.001$ & $<0.001$ & $<0.001$ \\
\hline \multirow{3}{*}{$\mathrm{LDH}$} & Pre-race & $400.5 \pm 27.4$ & $387.6 \pm 19.8$ & $401.3 \pm 19.1$ & $373.8 \pm 19.9$ \\
\hline & Post-race & $528.2 \pm 31.6$ & $668.8 \pm 56.9$ & $625.9 \pm 38.3$ & $529.9 \pm 27.5$ \\
\hline & $\mathrm{p}$ & $<0.001$ & $<0.001$ & $<0.001$ & $<0.001$ \\
\hline \multirow{3}{*}{ AST } & Pre-race & $400.1 \pm 14.9$ & $406.2 \pm 13.2$ & $401.6 \pm 10.3$ & $411.7 \pm 21.4$ \\
\hline & Post-race & $460.5 \pm 19.8$ & $523.7 \pm 25.0$ & $507.1 \pm 22.9$ & $496.6 \pm 27.7$ \\
\hline & $\mathrm{p}$ & $<0.001$ & $<0.001$ & $<0.001$ & $<0.001$ \\
\hline \multirow{3}{*}{ Urea } & Pre-race & $6.2 \pm 0.3$ & $6.1 \pm 0.3$ & $6.0 \pm 0.2$ & $6.3 \pm 0.3$ \\
\hline & Post-race & $7.9 \pm 0.3$ & $9.5 \pm 0.3$ & $8.8 \pm 0.3$ & $8.2 \pm 0.4$ \\
\hline & $\mathrm{p}$ & $<0.001$ & $<0.001$ & $<0.001$ & $<0.001$ \\
\hline \multirow{3}{*}{ Creatinine } & Pre-race & $100.6 \pm 2.3$ & $99.0 \pm 4.1$ & $99.6 \pm 3.2$ & $102.4 \pm 2.5$ \\
\hline & Post-race & $128.5 \pm 2.5$ & $139.6 \pm 5.8$ & $139.3 \pm 4.1$ & $127.7 \pm 3.3$ \\
\hline & $\mathrm{p}$ & $<0.001$ & $<0.001$ & $<0.001$ & $<0.001$ \\
\hline \multirow{3}{*}{ Cholesterol } & Pre-race & $2.5 \pm 0.1$ & $2.3 \pm 0.1$ & $2.4 \pm 0.1$ & $2.5 \pm 0.1$ \\
\hline & Post-race & $2.7 \pm 0.1$ & $2.5 \pm 0.1$ & $2.5 \pm 0.1$ & $2.7 \pm 0.1$ \\
\hline & $\mathrm{p}$ & 0.0002 & 0.0001 & 0.0002 & $<0.001$ \\
\hline \multirow{3}{*}{$\mathrm{Na}$} & Pre-race & $146.8 \pm 1.2$ & $147.1 \pm 1.8$ & $144.2 \pm 1.4$ & $151.5 \pm 1.3$ \\
\hline & Post-race & $145.9 \pm 1.2$ & $143.1 \pm 1.7$ & $142.6 \pm 1.3$ & $148.4 \pm 1.4$ \\
\hline & $\mathrm{p}$ & 0.2535 & 0.0009 & 0.1203 & 0.0307 \\
\hline \multirow{3}{*}{ K } & Pre-race & $3.5 \pm 0.1$ & $3.5 \pm 0.1$ & $3.5 \pm 0.1$ & $3.5 \pm 0.1$ \\
\hline & Post-race & $2.7 \pm 0.1$ & $2.6 \pm 0.1$ & $2.6 \pm 0.1$ & $2.6 \pm 0.1$ \\
\hline & $\mathrm{p}$ & $<0.001$ & $<0.001$ & $<0.001$ & $<0.001$ \\
\hline
\end{tabular}

CK, creatine kinase; LDH, lactate dehydrogenase; AST, aspartate aminotransferase; Na, sodium; K, potassium.

With regard to distance, longer races resulted in a significantly greater increase in CK ( $p<0.001)$, LDH $(p=0.004)$, AST $(p<0.001)$, creatinine $(\mathrm{p}<0.001), \mathrm{Na}(\mathrm{p}=$ $0.0314)$ and $\mathrm{Ca}(0.002)$ than shorter races. Horses with lower average speed recorded higher increases in the concentrations of LDH $(p=0.025)$, urea $(p=0.001)$ and creatinine $(\mathrm{p}<0.001)$ than horses with higher average speed.

The concentrations of glucose and triglyceride did not show significant changes before and after the races according to any of the studied categories. 
Correlation analysis and $\mathrm{p}$ values for tests of significance of the correlations are presented in Table 4. There were no significant correlations of GGT, glucose, triglycerides, cholesterol and $\mathrm{K}$ with any of the studied biochemical parameters.

Table 4. Correlations of changes in biochemical parameters in horses at endurance races.

\begin{tabular}{|c|c|c|c|c|c|c|c|c|}
\hline & CK & LDH & AST & Urea & Creatinine & $\mathrm{Na}$ & $\mathrm{Ca}$ & $\mathrm{Mg}$ \\
\hline CK & 1 & $0.84^{* * *}$ & $0.97 * * *$ & $0.44 *$ & $0.42 *$ & - & - & - \\
\hline LDH & & 1 & $0.83^{* * *}$ & $0.44^{*}$ & $0.43^{*}$ & - & $-0.48^{* *}$ & - \\
\hline AST & & & 1 & $0.43^{*}$ & $0.42^{*}$ & - & - & - \\
\hline Urea & & & & 1 & $0.76^{* * *}$ & - & - & - \\
\hline Creatinine & & & & & 1 & - & - & $0.47 * *$ \\
\hline $\mathrm{Na}$ & & & & & & 1 & $0.46^{* *}$ & - \\
\hline $\mathrm{Ca}$ & & & & & & & 1 & - \\
\hline $\mathrm{Mg}$ & & & & & & & & 1 \\
\hline
\end{tabular}

\section{DISCUSSION}

Changes in equine biochemical profiles during long endurance races can be attributed to a decreased blood volume, large energy expenditure and muscular damage [10]. In this study, a significant increase in values of $\mathrm{CK}, \mathrm{LDH}, \mathrm{AST}$, urea, creatinine and cholesterol were noted after the race at both longer $(80 \mathrm{~km})$ races and shorter $(40 \mathrm{~km})$ races.

Creatine kinase, LDH and AST are routinely measured to assess muscular status [18]. Creatine kinase concentration has a relatively rapid increase and decrease in response to strenuous exercise in horses, and it is considered a good indicator of training intensity and individual horse recovery [7]. The mild to moderate increase in serum concentration of CK before races is observed in healthy horses trained for endurance $[4,10]$. Our study confirmed this observation, since higher than normal concentrations of $\mathrm{CK}$ were observed in all horses prior to racing. This information is important to consider when assessing the health status of horses trained for endurance racing, due to deviations from the reference values of horses that are not in training or are competing in other non-endurance equine sports disciplines. The importance of tracking the concentration of $\mathrm{CK}$ in endurance horses was demonstrated in a study by Adamu et al. [14], where CK was useful in predicting race performance. In that study, $\mathrm{CK}$ was included in a metabolic disorder index (MDI), along with four other variables, which was used to predict the development of a metabolic disorder and, accordingly, exclude horses from further competition [14].

The concentration of LDH before the race was significantly higher in younger horses ( $<8$ years of age). This result is consistent with reference ranges given by Rossdales 
Laboratories [19] that compared the concentrations of LDH between horses of different ages. The total LDH concentrations are represented as age-dependent and it is suggested that reference ranges should be adjusted when interpreting results for young horses. Also, the change in the concentration of $\mathrm{LDH}$ after the race was increased in horses with lower average speed. The pronounced increase in LDH levels in slower horses observed in the present study could be a result of pronounced anaerobic metabolism and lower aerobic capacity [20]. Endurance horses with higher mean performance speed showed lower levels of LDH in biopsies of gluteus medius muscle than slower horses, indicating greater aerobic and lower anaerobic capacity of faster, and therefore better performance endurance horses [21].

Considering gender, females had significantly higher concentrations of LDH and AST prior to the race than males. Previous research has shown that mares are more often affected by recurrent exertional rhabdomyolysis [22,23], which could explain higher concentrations of muscle damage parameters in females than in males recorded in this study.

In this study, the increased values of musculoskeletal parameters $\mathrm{CK}, \mathrm{LDH}$ and AST recorded after the races is consistent with the results of previous research in horses trained for endurance racing $[4,6,10,24]$. In the present study, the increased concentrations of $\mathrm{CK}, \mathrm{LDH}$ and AST were significantly higher at $80 \mathrm{~km}$ compared to $40 \mathrm{~km}$ races. Increased serum muscle enzyme markers are a result of physiological consequence of endurance exercise in horses [25]. Given that strenuous exercise can result in increased $\mathrm{CK}, \mathrm{LDH}$, and AST plasma activities without any clinical signs of muscle damage and stiffness, it is rather difficult to differentiate between normal functional physiological muscle enzyme changes and pathological changes that are clinically significant [26].

In this study a positive correlation was found between changes in the concentrations of CK and urea, as well as in the concentrations of AST and urea. Severe cases of myopathy may develop a myoglobinuria that can cause acute kidney failure [27] leading to an increased concentration of urea. Since no horse in this research was excluded from the race due to metabolic problems, the damage indicated by the elevated concentrations of CK and AST was not clinically evident.

Compared to reference values, the increased concentration of urea was recorded before the races, which is commonly observed in horses trained for endurance racing [7]. During endurance training, re-absorption of osmotically active substance like urea is a part of the process of conserving water and sodium, inducing hypervolemia [28]. A study on horses competing in $121 \mathrm{~km}$ and $164 \mathrm{~km}$ endurance races concluded that the concentration of urea rises in horses after a prolonged effort [29]. This is consistent with the increase in post-race concentration of urea observed in our study. The increase in creatinine concentration after the races was also noted in a study on horses competing in a $160 \mathrm{~km}$ endurance race [4]. The same study [4] explained this increase as being a result of haemoconcentration, splenic contraction and decreased kidney 
perfusion during the race. In the present study, the significant positive correlation and the increased concentrations of urea and creatinine after the $80 \mathrm{~km}$ races is likely due to a higher degree of dehydration with intensified physical effort on the longer distance race. Observing different age groups, significantly higher concentrations of creatinine were obtained in older horses. A potential explanation would consider degenerative changes connected with age and subsequent lower efficiency of the kidneys under stress.

In this study, an increase in the concentration of GGT after the race was noted, albeit not statistically significant. During strenuous races in people, an elevated GGT level was attributed to oxidative stress and exercise intolerance [31,32]. Oxidative stress has been reported in endurance horses in response to both 40 and $80 \mathrm{~km}$ races [33].

The concentration of glucose before and after physical activity in this study was not significantly different, although an increase in concentration after the race has been noted, which was previously reported during a $160 \mathrm{~km}$ race [4]. Interestingly, in the present study, the pre-race glucose concentration was slightly higher than the reference value in approximately $90 \%$ of the horses. This increase is likely to be a result of sampling time, since most of the horses were fed within two hours prior to the race. Unlike other equestrian sports disciplines, where feeding horses just before physical activity is not desirable, in endurance racing feeding the horses before and during the race is extremely important [34]. Furthermore, pre-race hyperglycaemia can be caused by stress associated with horse transport [35] and probably with stress due to pre-race excitement.

Although Hyyppa et al. [36] noted that changes in the concentration of triglycerides in muscle fibres with exercise are difficult to interpret because of large individual variations, it has been shown that endurance-type exercise induces a decrease in muscle triglyceride content [37]. Though not statistically significant, this study showed a decrease in triglycerides concentration after the races. The lack of significance of triglycerides concentration in our study may be a result of the aforementioned considerable individual variations.

The significant increase in the concentration of cholesterol observed after the $80 \mathrm{~km}$ distance races is consistent with the study by Rose et al. [25] that followed serum biochemical parameters in 26 horses before and after competing in the $100 \mathrm{~km}$ endurance race. However, the increase in the concentration of cholesterol was not statistically significant after the $40 \mathrm{~km}$ endurance race in the present study. The increase in the concentration of cholesterol may be a consequence of lipid mobilization due to the intensive physical activity [38], which possibly occurs only at a certain threshold of activity, given the differences noted between the $40^{\text {th }} \mathrm{km}$ and $80 \mathrm{~km}$ distances in this study.

Horses' sweat contains relatively low concentrations of $\mathrm{Ca}, \mathrm{Mg}$ and $\mathrm{P}$ and high concentrations of $\mathrm{Na}, \mathrm{K}$ and $\mathrm{Cl}$ [39]. The decrease in the concentrations of $\mathrm{Na}$ and $\mathrm{K}$ after the race is a result of increased sweating and increased activity of $\mathrm{Na}-\mathrm{K}$ pumps 
during recovery $[4,7]$. Hypokalaemia is a cause of exhausted horse syndrome, as well as synchronous diaphragmatic flutter [40], both of which are serious metabolic disorders that require urgent veterinary intervention. An increase in the concentration of $\mathrm{Mg}$, although not statistically significant in the present study, is in agreement with other studies [6,41] that evaluated endurance horses competing at distances above $90 \mathrm{~km}$. The increase in the concentrations of $\mathrm{Mg}$ is attributed to haemoconcentration due to dehydration [6]. Although there was no significant difference in the concentration of $\mathrm{Ca}$ before and after the races, the change in the concentration of Ca was significantly higher at longer races than at short races in the present study. According to a study on endurance horses competing at high-speed in $160 \mathrm{~km}$ races, lower concentration of $\mathrm{Ca}$ could be attributed to a greater electrolyte loss due to increased sweating of the horse [4].

This research contains certain limitations that need to be emphasized. The enrolment into the study was voluntary and it did not include all the participating horses. Another limitation was a lack of standardized feeding or detailed nutritional surveys to determine the intake level of electrolytes, even though most of the horses were fed with balanced formulas for endurance horses. Horses that participated in competitions had been transported from different locations before the race, which may have induced stress and influenced the results. Since all the animals were given a period of rest and were declared fit to compete by veterinary examination prior to the blood sampling, it was assumed that the transportation effect had a negligible effect. Finally, the samples could not have been analyzed for parameters that would add additional information regarding dehydration (haematocrit, total proteins and albumins); however, we were not able to perform those analyses due to limited financial resources.

\section{CONCLUSIONS}

The present study showed that endurance riding caused increased body requirements manifested by intensified electrolyte loss, increased muscular and urinary system activity regardless of the race distance. Longer races and lower average speed caused more pronounced increases in renal parameters and biochemical markers of muscle damage. However, it is important to emphasize that even at shorter races same changes were noted, albeit less pronounced. Creatine kinase and blood glucose values prior to the race were higher than reference values, which should be taken into account when evaluating the health and fitness status of endurance horses in training.

\section{Acknowledgements}

The authors greatly acknowledge all the horses' owners and riders who participated in the study, as well as organizers and judges of the endurance races for their cooperation during data collection. The authors wish to thank the Croatian Equestrian Federation for their support. 


\section{Author's contributions}

BBN and $\mathrm{VZ}$ conceived and designed the study. KK, BBN, VZ, GJ and BT were involved in the acquisition and interpretation of data. KK drafted the manuscript. BK performed the statistical analyses. BBN, VZ, GJ and BK revised the manuscript critically for important intellectual content. All authors gave a final approval of the version to be published and agree to be accountable for all aspects of the work in ensuring that questions related to the accuracy or integrity of any part of the work are appropriately investigated and resolved.

\section{Declaration of conflicting interests:}

The author(s) declared no potential conflicts of interest with respect to the research, authorship, and/or publication of this article.

\section{Statement of Informed Consent}

The owner understood procedure and agrees that results related to investigation or treatment of their companion animals could be published in this journal.

\section{REFERENCES}

1. McKeever KH: Body fluids and electrolytes. In: Equine Exercise Physiology - The Science of Exercise in the Athletic Horse. Hinchchcliff KW, Geor RJ, Kaneps AJ, editors. Philadelphia, PA: Elsevier Limited; 2008, 328-49.

2. Siqueira RF, Weigel RA, Nunes GR, Mori CS, Fernandes WR: Oxidative profiles of endurance horses racing different distances. Arq Bras Med Vet Zootec 2014, 66:455-461.

3. Flaminio MJ, Rush BR: Fluid and electrolyte balance in endurance horses. Vet Clin North Am Equine Pract 1998, 14:147-58.

4. Schott HC, Marlin RJ, Geor RJ, Holbrooks TC, Deaton CM, Vincent T, Dacrey K, Schroter RC, Jose-Cunillera E, Cornelisse CJ: Changes in selected physiological and laboratory measurements in elite horses competing in a $160 \mathrm{~km}$ endurance ride. Equine Vet J 2006, 36:37-42.

5. Misheff MM: Lameness in endurance horses. In: Diagnosis and management of lameness in the horse. Ross MW, Dyson SJ, editors. 2nd ed. St Louis, Elsevier Saunders. 2011, 1137-1149.

6. Muñoz A, Riber C, Trigo P, Castejón-Riber C, Castejón F: Dehydration, electrolyte imbalances and renin-angiotensin-aldosterone-vasopressin axis in successful and unsuccessful endurance horses. Equine Vet J 2010, 42:83-90.

7. Robert C: Veterinary aspects of training and racing endurance horses. In: Equine Sports Medicine and Surgery. Hinchcliff KW, Kaneps AJ, Geor RJ, editors. 2nd ed. Elsevier: WB Saunders. 2014, 1083-1104.

8. Robert C, Goachet AG, Fraipont A, Votion DM, Van Erck E, Leclerc JL: Hydration and electrolyte balance in horses during an endurance season. Equine Vet J 2010, 42:98-104. 
9. Thomas DP, Fregin GF: Endurance training-induced hypervolemia in the horse. Med Sci Sports Exerc 1987, 19:524-5.

10. Larsson J, Pilborg PH, Johansen M, Christophersen MT, Holte A, Roepstorff L, Olsen LH, Harrison AP: Physiological Parameters of Endurance Horses Pre-Compared to Post-Race, Correlated with Performance: A Two Race Study from Scandinavia. ISRN Vet Sci 2013, 684353.

11. Treiber KH, Kronfeld DS, Hess TM, Byrd BM, Splan RK, Staniar WB: Evaluation of genetic and metabolic predispositions and nutritional risk factors for pasture-associated laminitis in ponies. J Am Vet Med Assoc 2006, 228:1538-1545.

12. Ridgeway, K.J: Training endurance horses. In: The Athletic Horse Principles and Practice of Equine Sports Medicine. Eds. Hodgson D.R. and Rose, R.J., W.B. Saunders, Phil. Pa, USA, 1994, 409-411.

13. Adamu L, Adzahan MN, Rasedee A, Ahmad B: Responses of serum biochemical parameters, electrolytes and heart rate in and 80km endurance race. J Vet Adv 2014, 4:329-337.

14. Adamu L, Rasedee LAF, Mohd Adzahan N, Rasedee A, Ahamad B: The use of a metabolic disorder index as a predictor for metabolic eliminations in endurance horses. J Equine Vet Sci 2017, 51:113-121.

15. Federation Equestre Internationale: Endurance rules, 2018. [https:// inside.fei.org/sites/ default/files/Endurance Rules_2018_clean.pdf]

16. The R Project for Statistical Computing [http://www.R-project.org/]

17. Bates D, Maechler M, Bolker B, Walker S: Fitting Linear Mixed-Effects Models Using lme4. J Stat Softw 2015, 67:1-48.

18. Da Cás EL, Brass KE, Greig CR, Deprá NM, Silva CAM: Concentrações de creatino quinase, aspartato aminotransferase e desidrogenase lática em potros do nascimento até os seis meses de idade. Cienc Rural 2001, 31:1003-6.

19. Rossdales Laboratories: Lactate Dehydrogenase (LDH) [https://www.rossdales.com/ laboratories/tests-and-diseases/lactate-dehydrogenase-ldh]

20. Votion D: Metabolic responses to exercise and training. In: Equine Exercise Physiology The Science of Exercise in the Athletic Horse. Hinchchcliff KW, Geor RJ, Kaneps AJ, editors. Philadelphia, PA: Elsevier Limited; 2008 747-767.

21. Rivero JL, Serrano AL, Henckel P: Activities of selected aerobic and anaerobic enzymes in the gluteus medius muscle of endurance horses with different performance records. Vet Rec 1995, 137:187-92.

22. MaCleay JM, Sorum SA, Valberg SJ, Marsh WE, Sorum MD: Epidemiologic analysis of factors influencing exertional rhabdomyolysis in Thoroughbreds. Am J Vet Res 1999, 60:1562-1566.

23. McGowan CM, Fordham T, Christley M: Incidence and risk factors for exertional rhabdomyolysis in Thoroughbred racehorses in the United Kingdom. Vet Rec 2002, 151:623-626.

24. Adamu L, Noraniza MA, Rasedee A, Bashir A: Metabolic responses in endurance horses during racing in relation to uric acid profile, leucocytes, heart rate and plasma biochemical parameters. Vet Med 2012, 57:591-596.

25. Rose R, Purdue RA, Hensley W: Plasma Biochemistry Alterations in Horses during an Endurance Ride. Equine Vet J 1977, 9:122-126. 
26. Muñoz A, Riber C, Santisteban R, Lucas RG, Castejón FM: Effect of training duration and exercise on blood-borne substrates, plasma lactate and enzyme concentrations in Andalusian, Anglo-Arabian and Arabian breeds. Equine Vet J 2002, 34:245-51.

27. Piercy RJ, Rivero J: Muscle disorders of equine athletes. In: Equine Sports Medicine and Surgery. Hinchcliff KW, Kaneps AJ, Geor RJ, editors. 2nd ed. Elsevier: WB Saunders. 2014, 109-143.

28. McKeever KH, Schurg WA, Jarrett SH, Convertino VA: Exercise training-induced hypervolemia in the horse. Med Sci Sports Exerc 1987, 19:21-7.

29. Castejon F, Trigo P, Muñoz A, Riber C: Uric acid responses to endurance racing and relationships with performance, plasma biochemistry and metabolic alterations. Equine Vet J 2006, 36:70-13.

30. Parkin TD: Epidemiology of racetrack injuries in racehorses. Vet Clin North Am Equine Pract 2008, 24:1-19.

31. Lee DH, Jacobs DR. Association between serum gamma glutamyltransferase and C-reactive protein. Atherosclerosis 2005, 178:327-330.

32. Yang HK, Hong KM, Seok MS, Kim IJ, Yong KK: The association of serum gamma glutamyltransferase with components of the metabolic syndrome in the Korean adults. Diab Res Clin Prac 2007, 77:306-313.

33. Brkljača Bottegaro N, Gotić J, Šuran J, Brozić D, Klobučar K, Bojanić K, Vrbanac Z: Effect of prolonged submaximal exercise on serum oxidative stress biomarkers (d-ROMs, MDA, BAP) and oxidative stress index in endurance horses. BMC Vet Res 2018, 14:216.

34. Harris P: Feeding Management of Elite Endurance Horses. Vet Clin Equine Pract 2009, 25:137-153.

35. Tateo A, Padalino B, Boccaccio M, Maggiolino A, Centoducati P: Transport stress in horses: Effects of two different distances. Journal of Veterinary Behavior: Clinical Applications and Research 2012, 7:33-42.

36. Hyyppa S, Saastamoinen M, Reeta Poso A: Effect of a post exercise fat supplemented diet on muscle glycogen repletion. Equine Vet J 1999, 30:493-8.

37. Essén-Gustavsson B, Karlstrom K, Lindholm A: Fibre types, enzyme activities and substrate utilisation in skeletal muscles of horses competing in endurance rides. Equine Vet J 1984, 16:197-202.

38. Jovic S, Stevanovic J, Borozan S, Dimitrijevic B, Popovic T, Blagojevic M: Lipid status in racehorses following physical activity of various intensity and duration. Acta Vet-Beograd 2013, 63:211-226.

39. McCutcheon LJ, Geor RJ: Sweat fluid and ion losses in horses during training and competition in cool vs. hot ambient conditions: implications for ion supplementation. Equine Vet J 1996, 28:54-62.

40. McGowan CM, Geor RJ: Endocrine and metabolic disorders of the equine athlete. In: Equine Sports Medicine and Surgery. Hinchcliff KW, Kaneps AJ, Geor RJ, editors. 2nd ed. Elsevier: WB Saunders. 2014, 787-796.

41. Sloet Van Olrdruitenborgh-Oosterbaan MM, Wesing T, Barnevald A, Breukink HJ: Heart rate, blood biochemistry and performance of horses competing in a $100 \mathrm{~km}$ endurance ride. Vet Rec 1991, 128:175-9. 


\title{
PROMENE BIOHEMIJSKIH PARAMETARA KOD KONJA TOKOM DALJINSKOG JAHANJA NA 40 KM I 80 KM
}

\author{
KLOBUČAR Karla, VRBANAC Zoran, GOTIĆ Jelena, BOJANIĆ Krunoslav, \\ BUREŠ Tomislav, BRKLJAČA BOTTEGARO Nika
}

Tokom intenzivne fizičke aktivnosti konji su izloženi termolizi, gubitku elektrolita i povećanom stvaranju produkata metabolizma, što za posledicu ima promene biohemijskih parametara krvi usled prilagođavanja konja na metabolički stres. Cilj ovog istraživanja bio je da se utvrdi uticaj intenzivne fizičke aktivnosti na serumske, biohemijske parametre kod konja koji se takmiče na trkama daljinskog jahanja dužine 40 i $80 \mathrm{~km}$. Uzorci krvi uzeti su od 28 konja, pre i posle trke tokom četiri takmičenja, sa ukupno 53 analizirana uzorka. Biohemijski parametri uključivali su: kreatin kinazu, laktat dehidrogenazu, aspartat aminotransferazu, ureu, kreatinin, gamaglutamil transferazu, glukozu, trigliceride, holesterol, natrijum, kalijum, kalcijum i magnezijum. Opseg promene vrednosti pre i posle trke upoređen je između kategorija starosti, pola, rase, udaljenosti i prosečne brzine konja. Vrednosti kreatin kinaze i glukoze u krvi pre trke bile su više od referentnih vrednosti. Vrednosti bubrežnih parametara i parametara oštećenja mišića povećavale su se posle trke, a stepen promene bio je izraženiji na dužim trkama, kao i pri nižoj prosečnoj brzini. Gubitak elektrolita bio je izraženiji tokom dužih trka. Ovo istraživanje pokazalo je da daljinsko jahanje uzrokuje očigledne promene u koncentracijama elektrolita u serumu, bubrežnim parametrima i markerima oštećenja mišića kod konja. Navedene promene vidljive su kod konja na kratkim i dugim trkama daljinskog jahanja. 